\title{
Accumulation of Pharmaceuticals, Enterococcus, and Resistance Genes in Soils Irrigated with Wastewater for Zero to 100 Years in Central Mexico
}

\author{
Philipp Dalkmann ${ }^{1 * 9}$, Melanie Broszat ${ }^{2,39}$, Christina Siebe ${ }^{4}$, Elisha Willaschek ${ }^{1}$, Tuerkan Sakinc ${ }^{2}$, \\ Johannes Huebner ${ }^{2}$, Wulf Amelung ${ }^{1}$, Elisabeth Grohmann ${ }^{2}$, Jan Siemens ${ }^{1}$
}

1 Institute of Crop Science and Resource Conservation - Soil Science and Soil Ecology, University of Bonn, Bonn, Germany, 2 Department of Infectious Diseases, University Hospital Freiburg, Freiburg, Germany, 3 Faculty for Biology, Microbiology, Albert-Ludwigs-University Freiburg, Freiburg, Germany, 4 Instituto de Geología, Universidad Nacional Autónoma de México, México D.F., México

\begin{abstract}
Irrigation with wastewater releases pharmaceuticals, pathogenic bacteria, and resistance genes, but little is known about the accumulation of these contaminants in the environment when wastewater is applied for decades. We sampled a chronosequence of soils that were variously irrigated with wastewater from zero up to 100 years in the Mezquital Valley, Mexico, and investigated the accumulation of ciprofloxacin, enrofloxacin, sulfamethoxazole, trimethoprim, clarithromycin, carbamazepine, bezafibrate, naproxen, diclofenac, as well as the occurrence of Enterococcus spp., and sul and qnr resistance genes. Total concentrations of ciprofloxacin, sulfamethoxazole, and carbamazepine increased with irrigation duration reaching $95 \%$ of their upper limit of $1.4 \mu \mathrm{g} / \mathrm{kg}$ (ciprofloxacin), $4.3 \mu \mathrm{g} / \mathrm{kg}$ (sulfamethoxazole), and $5.4 \mu \mathrm{g} / \mathrm{kg}$ (carbamazepine) in soils irrigated for 19-28 years. Accumulation was soil-type-specific, with largest accumulation rates in Leptosols and no time-trend in Vertisols. Acidic pharmaceuticals (diclofenac, naproxen, bezafibrate) were not retained and thus did not accumulate in soils. We did not detect qnrA genes, but qnrS and $q n r B$ genes were found in two of the irrigated soils. Relative concentrations of sul1 genes in irrigated soils were two orders of magnitude larger $\left(3.15 \times 10^{-3} \pm 0.22 \times 10^{-3}\right.$ copies/16S rDNA) than in non-irrigated soils $\left(4.35 \times 10^{-5} \pm 1.00 \times 10^{-5}\right.$ copies/16S rDNA), while those of sul2 exceeded the ones in nonirrigated soils still by a factor of $22\left(6.61 \times 10^{-4} \pm 0.59 \times 10^{-4}\right.$ versus $2.99 \times 10^{-5} \pm 0.26 \times 10^{-5}$ copies/16S rDNA). Absolute numbers of sul genes continued to increase with prolonging irrigation together with Enterococcus spp. 23S rDNA and total $16 \mathrm{~S}$ rDNA contents. Increasing total concentrations of antibiotics in soil are not accompanied by increasing relative abundances of resistance genes. Nevertheless, wastewater irrigation enlarges the absolute concentration of resistance genes in soils due to a long-term increase in total microbial biomass.
\end{abstract}

Citation: Dalkmann P, Broszat M, Siebe C, Willaschek E, Sakinc T, et al. (2012) Accumulation of Pharmaceuticals, Enterococcus, and Resistance Genes in Soils Irrigated with Wastewater for Zero to 100 Years in Central Mexico. PLoS ONE 7(9): e45397. doi:10.1371/journal.pone.0045397

Editor: Mark R. Liles, Auburn University, United States of America

Received June 6, 2012; Accepted August 22, 2012; Published September 25, 2012

Copyright: (c) 2012 Dalkmann et al. This is an open-access article distributed under the terms of the Creative Commons Attribution License, which permits unrestricted use, distribution, and reproduction in any medium, provided the original author and source are credited.

Funding: This work was supported by grants (FI1106/5-1 and GR1792/4-1) from the German Research Foundation (DFG; http://www.dfg.de). The funders had no role in study design, data collection and analysis, decision to publish, or preparation of the manuscript.

Competing Interests: The authors have declared that no competing interests exist.

* E-mail: philipp.dalkmann@uni-bonn.de

9 These authors contributed equally to this work.

\section{Introduction}

The coexistence of antibiotics, pathogenic bacteria, and resistance determinants in the environment raises concerns that antibiotic resistance genes are mobilized from and disseminated into the environmental resistome and transferred to bacteria that are potentially pathogenic to humans $[1,2,3]$. These risks might be particularly high for agricultural fields that are irrigated with wastewater, which receive regular inputs of antibiotics, bacteria, and resistance genes similar to manured soils (e.g., [4]). Nevertheless, climate change, population growth, as well as urbanization increase the pressure on water resources in many regions of the world $[5,6]$. Thus, the pressure of re-using wastewater for irrigation and food production (e.g., [7,8]) or to recharge groundwater for drinking water supply (e.g., $[9,10])$ is increasing rather than decreasing, with unforeseen risks in the long-term.
One of the largest wastewater irrigation areas worldwide can be found in the Mezquital Valley receiving wastewater from the Mexico City Metropolitan Area (MCMA) [11]. Gibson et al. $[12,13]$ as well as Siemens et al. [14] already documented that this wastewater contains a wide range of pharmaceuticals. Consequently, pharmaceuticals have also been found in soils irrigated with MCMA wastewater [13,15]. Reports on the occurrence of pharmaceuticals in wastewater-irrigated soils in Colorado, USA [16], Braunschweig, Germany [17], Hebei, China [18], and the metropolitan area of Paris, France [19] illustrate that the contamination of soils with wastewater-derived pharmaceuticals is not limited to Mexico, but a global phenomenon.

Along with pharmaceuticals, certain bacterial species, part of which are pathogenic or resistant to antibiotic agents or both, are released into wastewater irrigation channels and fields (e.g., $[20,21,22])$. Bacteria resistant to antibiotics have been isolated previously from wastewater-irrigated fields in India [23]. 
Enterococcus spp. are commonly used as hygienic indicator in the environment since they mainly originate from animal and human faeces [24]. In wastewater the predominant species are $E$. faecalis, E. faecium and E. hirae $[25,26,27,28]$. E. faecalis and E. faecium are currently also the third most commonly isolated nosocomial pathogens worldwide and the second most common nosocomial pathogens isolated from intensive care patients worldwide $[29,30,31,32]$. Acquired antibiotic resistances in enterococci are reported in an increasing number of hospital isolates [29]. Whether the abundance of such organisms increases in soil with repeated wastewater application has not been studied yet, to our knowledge.

Several investigations have studied the occurrence of antibiotic resistance genes in different environmental compartments including wastewater, wastewater lagoons, surface waters, river sediments, pristine soils, and manured soils (e.g., $[33,34,35,36,37,38,39])$. Very limited information is, however, available on the presence of antibiotic resistance genes in soils to which wastewater or biosolids have been applied [40]. All these studies reached the conclusion that antibiotic resistance genes are comparable to "emerging contaminants" that need to be further studied. It is important to note, however, that resistance genes do not only enter the environment with livestock or human waste, but are common also in rather pristine environments, especially in soils (e.g., $[1,41])$. Recent laboratory experiments with E. coli and Salmonella enterica showed that a selection of antibiotic resistance occurs at very small sub-inhibitory concentrations of antibiotics that are usually encountered in polluted environments [42]. Of particular concern for public health is the selection of genes conferring resistance towards sulfonamides and fluoroquinolones. Sul resistance genes (sul1, sul2) conferring resistance to sulfonamides occur in a wide range of bacterial species, because they are often encoded on transposable elements of conjugative or mobilizable broad-host-range plasmids [38,43,44]. The fluoroquinolone resistance genes $q n r A$, $q n r B$, and $q n r S$ are also often plasmid-encoded, threatening to accelerate the spread of resistance through horizontal transfer [37]. Quinolone resistance is on the rise, especially among the Enterobacteriacae $[45,46]$. The relevance of these resistance genes for public health is reflected by the fact that sul1 and sul 2 have been detected in a variety of clinical Enterobacteriaceae isolates (e.g., [47]), the qnr genes in many clinical Klebsiella pneumoniae isolates and in $E$. faecalis $[48,49,50,51]$.

In summary, the presence of pharmaceuticals in wastewaterirrigated soils has been documented for several sites. However, it is currently unclear whether and to which degree continuous irrigation with wastewater may lead to a long-term accumulation of these agents in soil. We hypothesize that similar to the changes of natural organic matter with prolonged land-use (e.g., $[52,53,54])$ a steady state in soil is approached between input with wastewater, decay, and output of pharmaceuticals with drainage and harvested crops (assuming constant input). Yet, our knowledge on how fast and to which degree this steady state is reached after prolonged wastewater irrigation is unknown. As the accumulation of pharmaceuticals may be associated with the accumulation of resistance genes derived from wastewater or the "native" soil resistome, we included the analysis of resistance genes and Enterococcus ssp. into our assessment of soil contamination in the Mezquital Valley, Mexico. The studied soils received untreated MCMA wastewater from zero to 100 years; soils under rainfed irrigation served as control.

\section{Materials and Methods}

\section{Soils}

Over the past century the irrigated area in the Mezquital Valley increased due to the expansion of the MCMA. We chose sites with different duration of irrigation with untreated wastewater $(0,1.5$, $3,6,8,11,12,13.5,23,35,50,85$, and 100 years) for our study, each of which was either sampled between June and August 2009 or in March 2011. The second sampling campaign in March 2011 was necessary to increase the temporal resolution of the soil chronosequence particularly for the short irrigation periods (a detailed list of samples can be found in Table S1 in the supporting information, SI). Depending on their clay content and the thickness of the solum the soils in the Mezquital Valley have been classified as Leptosols, Vertisols, and Phaeozems [8] according to the World Reference Base for Soil Resources [55]. Soil properties are given in Table 1. All soils have been irrigated with MCMA wastewater, which has been well mixed especially over longer time periods because of the extensive pumping and diversion of wastewater within the MCMA and the Mezquital Valley irrigation system. Each individual field was subdivided into four parcels, two on the wastewater inflow side and two on the wastewater outflow side of the field. From each parcel a sample composed of twelve subsamples was taken with an auger at a depth of $0-30 \mathrm{~cm}$. Soil samples were collected in plastic bags, transported to the laboratory in cooling bags (around $4^{\circ} \mathrm{C}$ ) and stored at $-21^{\circ} \mathrm{C}$ until extraction.

\section{Pharmaceutical Agents}

Based on consumption data of Mexico [56] and ecotoxicological relevance, research concentrated on the compounds ciprofloxacin, enrofloxacin, sulfamethoxazole, trimethoprim, clarithromycin, carbamazepine, bezafibrate, naproxen, and diclofenac, the standards of which were obtained from Sigma-Aldrich (Schnelldorf, Germany). Important physicochemical properties of these compounds are listed in Table 2. Isotope-labeled ciprofloxacin (carboxyl- ${ }^{13} \mathrm{C}_{3}$, quinoline- ${ }^{15} \mathrm{~N}, \geq 98 \%$ pure), enrofloxacin hydrochloride (ethyl- $\mathrm{d}_{5}, \geq 98 \%$ pure), sulfamethoxazole (ring- ${ }^{13} \mathrm{C}_{6}$, $\geq 98 \%$ pure), trimethoprim (methyl- ${ }^{13} \mathrm{C}_{3}, \geq 98 \%$ pure), and carbamazepine (phenyl- $\mathrm{d}_{10}, \geq 98 \%$ pure) were supplied by LGC Standards (Wesel, Germany) as internal standards. Labeled bezafibrate (phenyl- $\mathrm{d}_{4},>98 \%$ pure) and clarithromycin (methyl$\mathrm{d}_{3}, 98 \%$ pure) were obtained from Toronto Research Chemicals (North York, Canada). Labeled naproxen (methyl- $\mathrm{d}_{3}, 98 \%$ pure) and diclofenac (phenyl- $\mathrm{d}_{4}, 99 \%$ pure) were purchased from Dr. Ehrenstorfer (Augsburg, Germany).

\section{Extraction of Pharmaceuticals from Soil and their Detection}

Soil samples were lyophilized and sieved to a grain size $<2 \mathrm{~mm}$. We distributed ten grams of dry matter (DM) of each soil into borosilicate centrifuge glasses. The extraction of an easily extractable, "bioaccessible" compound fraction was performed with $25 \mathrm{~mL}$ of a $0.01 \mathrm{M} \mathrm{CaCl}_{2}$ solution [57]. To assess the strongly bound, sequestered fraction of pharmaceuticals in soil, the $\mathrm{CaCl}_{2}$ extracted soil samples were lyophilized again and extracted via accelerated solvent extraction (ASE). We combined two different solvents for the extraction to account for the different physicochemical properties of the pharmaceuticals (Table 2). We used an aqueous $50 \mathrm{mM}$ phosphoric acid:acetonitrile solution (50:50, v/v; according to Golet et al. [58] and a methanol:water solution (50:50, v/v; according to Gobel et al. [59]). Extraction recoveries of the extraction method varied between 54-95\% (Table S2 in the SI). 
Table 1. Soil properties.

\begin{tabular}{|c|c|c|c|c|c|c|}
\hline Soil type & $\begin{array}{l}\text { Clay content }{ }^{\mathrm{a}} \\
\text { (range) }[\%]\end{array}$ & $\begin{array}{l}\text { Clay content }{ }^{\mathrm{a}} \\
\text { (mean) }[\%]\end{array}$ & $\begin{array}{l}\text { OC content } \\
\text { (range) }[\%]\end{array}$ & $\begin{array}{l}\text { OC content } \\
\text { (mean) }[\%]\end{array}$ & pH (range) & pH (mean) \\
\hline Leptosols (LP) & $18.6-39.1$ & 31.6 & $1.1-2.4$ & 1.9 & $6.6-8.2$ & 7.5 \\
\hline Phaeozems (PH) & $15.6-31.9$ & 22.6 & $1.2-2.7$ & 1.8 & $6.8-8.0$ & 7.3 \\
\hline Vertisols (VR) & $28.9-54.4$ & 43.5 & $1.6-2.6$ & 2.2 & $6.3-7.7$ & 7.1 \\
\hline
\end{tabular}

${ }^{\text {a }}$ Data are from Siebe [73];

borganic carbon (OC) content.

doi:10.1371/journal.pone.0045397.t001

The analysis of pharmaceutical concentrations in soil extracts was performed with liquid chromatography tandem mass spectrometry (LC-MS/MS). Routine limit of quantification $(\mathrm{RLOQ}=$ lowest concentration of standard used) were $42 \mathrm{ng} / \mathrm{kg}$ dry soil in the $\mathrm{CaCl}_{2}$-extracts (naproxen: $428 \mathrm{ng} / \mathrm{kg}$ ) and $57 \mathrm{ng} / \mathrm{kg}$ in the ASE-extracts (naproxen: $570 \mathrm{ng} / \mathrm{kg}$ ). A detailed description of the extraction procedure and the analyses of pharmaceutical concentrations can be found in Text $\mathrm{S} 1$, Text $\mathrm{S} 2$, and Table S3 in the SI.

\section{Quantification of Antibiotic Resistance Genes and Enterococci in Soil Samples}

Aliquots of soil samples from fields of the chronosequence irrigated for $0,1.5,3,6,8,85$, and 100 years were analyzed by real-time qPCR, in the following denominated as qPCR. We did not analyze soil samples of other irrigation durations specified above, because these samples were transported with $24 \mathrm{~h}$ delay from Mexico to Germany by the airline and were partly thawed by arrival. For each composite sample we pooled $10 \mathrm{~g}$ of the four parcels. Total DNA was extracted from $500 \mathrm{mg}$ soil using the NucleoSpin ${ }^{\circledR}$ Soil kit according to the manufacturer's protocol (Macherey-Nagel, Düren, Germany). Absolute quantifications of 16S rDNA, sul1, sul2, qnrA, qnrB, qnrS, and Enterococcus spp. $23 \mathrm{~S}$ rRNA genes were performed with serial diluted exogenous standards that consisted of purified PCR products. PGR products were purified with QIAquick Gel Extraction Kit (Qiagen, Hilden, Germany).

Quantification of absolute target gene numbers was carried out using the Light-Cycler 480 (Roche Diagnostics, Mannheim,

Table 2. Compound properties and measurement details.

\begin{tabular}{|c|c|c|c|c|c|c|c|c|c|}
\hline Compound & $\begin{array}{l}\text { Water } \\
\text { solubility a,b } \\
\text { [g/L] }\end{array}$ & $\log P_{\text {ow }}{ }^{b}$ & $\begin{array}{l}\mathrm{K}_{\mathrm{OC}} \\
\text { [L/kg] }\end{array}$ & $\mathbf{p K}_{\mathrm{a}}^{\mathrm{b}}$ & $\begin{array}{l}\text { Excretion } \\
\text { rate }^{c}[\%]\end{array}$ & $\begin{array}{l}\mathrm{PEC}^{\mathbf{d}} \\
{[\mu \mathrm{g} / \mathrm{L}]}\end{array}$ & $\begin{array}{l}\text { Precursor } \\
\text { lon }[\mathrm{m} / \mathrm{z}]\end{array}$ & $\begin{array}{l}\text { Daughter } \\
\text { lons }[\mathrm{m} / \mathrm{z}]\end{array}$ & $\begin{array}{l}\text { Collision } \\
\text { Energy [eV] }\end{array}$ \\
\hline \multirow[t]{2}{*}{ ciprofloxacin } & 0.5 & 1.63 & $3487^{e}$ & $6.4 ; 8.7$ & 20.0 & 0.30 & 332.09 & 245.06 & 24 \\
\hline & & & & & & & & 288.11 & 17 \\
\hline \multirow[t]{2}{*}{ enrofloxacin } & 0.1 & 2.31 & $2179^{e}$ & $6.4 ; 7.8$ & n.a. ${ }^{9}$ & n.a. ${ }^{9}$ & 360.12 & 245.06 & 26 \\
\hline & & & & & & & & 316.16 & 18 \\
\hline \multirow[t]{2}{*}{ sulfamethoxazole } & 2.8 & 0.66 & $219^{f}$ & $5.8 ; 1.4$ & 30.0 & 1.96 & 254.02 & 108.03 & 23 \\
\hline & & & & & & & & 155.97 & 15 \\
\hline \multirow[t]{2}{*}{ trimethoprim } & 1.0 & 0.59 & $301^{f}$ & 7.0 & 80 & 1.05 & 291.10 & 123.06 & 32 \\
\hline & & & & & & & & 230.09 & 23 \\
\hline \multirow[t]{2}{*}{ clarithromycin } & 460.0 & 2.81 & $64.4^{\mathrm{b}}$ & $13.1 ; 8.2$ & 25.0 & 0.09 & 748.43 & 158.00 & 28 \\
\hline & & & & & & & & 590.23 & 18 \\
\hline \multirow[t]{2}{*}{ carbamazepine } & 0.2 & 1.90 & $363^{f}$ & 13.9 & 3.0 & 0.03 & 237.08 & 179.08 & 34 \\
\hline & & & & & & & & 194.10 & 20 \\
\hline \multirow[t]{2}{*}{ naproxen } & 15.0 & 2.88 & $302^{f}$ & 4.8 & 5.5 & 0.43 & 231.08 & 170.08 & 26 \\
\hline & & & & & & & & 185.10 & 12 \\
\hline \multirow[t]{2}{*}{ diclofenac } & 2.3 & 4.55 & $245^{f}$ & 4.2 & 5.5 & 0.06 & 296.00 & 214.02 & 35 \\
\hline & & & & & & & & 250.02 & 13 \\
\hline \multirow[t]{2}{*}{ bezafibrate } & 140.0 & 2.50 & $398^{f}$ & 3.3 & 50.0 & 0.10 & 362.08 & 121.06 & 29 \\
\hline & & & & & & & & 138.97 & 26 \\
\hline
\end{tabular}

at $\mathrm{pH} 7$ and $25^{\circ} \mathrm{C}$;

${ }^{b}$ Data are from SciFinder Database (https: $\backslash \backslash$ scifinder.cas.org), accessed May 2, 2012;

'Data are from Verlicchi et al. [74];

${ }^{d}$ Predicted Environmental Concentration (including excretion rate, mean 2003/2004);

${ }^{\text {e}}$ Data are from Figuero-Diva et al. [75];

fData are from Barron et al. [76];

${ }^{g}$ not available.

doi:10.1371/journal.pone.0045397.t002 
Germany). The limit of quantification (LOQ for sul1, sul2, qnrB, and $q n r S$ was 10 gene copies/reaction. For $16 \mathrm{~S}$ rDNA, Enterococcus spp. and qnrA the limit of quantification equaled 100 gene copies/ reaction. Reagents and programs for qPCR are listed in Table S4 and S5 of the SI. A detailed description of the method can be found in Text S3 in the SI.

\section{Data Evaluation}

The substance amounts in the $\mathrm{CaCl}_{2}$ - and ASE-extracts were summed to determine the total extractable pharmaceuticals in the soils. A model of exponential dissipation at constant inflow (equation 1) was fitted to the measured total soil concentrations,

$$
\frac{d C}{d t}=A-k * C
$$

with $C$ denoting the concentration in soil $[\mu \mathrm{g} / \mathrm{kg}], t$ denoting the irrigation period [yr], $A$ the compound inflow $\left[\mu \mathrm{g} / \mathrm{kg}^{*} \mathrm{yr}\right]$, and $k$ denoting the dissipation rate constant $[1 / \mathrm{yr}]$. In this context "dissipation" includes all processes leading to a decrease of extractable concentrations in soil, such as biodegradation, photolysis, volatilization, leaching, plant uptake, and sequestration in nonextractable residues. Following integration, the concentration of pharmaceuticals in soil at a given point of time equals (eq. 2)

$$
C(t)=\frac{\left(k * C_{0}-A\right) * e^{-k * t}+A}{k}
$$

with $\mathrm{C}(\mathrm{t})$ denoting the concentration $[\mu \mathrm{g} / \mathrm{kg}]$ at a given point of time and $\mathrm{C} 0$ the concentration at the start of irrigation $[\mu \mathrm{g} / \mathrm{kg}]$.

Predicted environmental concentrations (PEC, $\mu \mathrm{g} / \mathrm{L}$ ) of the pharmaceuticals in wastewater were calculated according to equation 3 (after [14]),

$$
P E C=\frac{S * F * E * 10^{9}}{V * 365}
$$

with $S$ denoting the active moiety of the pharmaceutical sold in Mexico $[\mathrm{kg} / \mathrm{yr}], V$ denoting the water flow through the MCMA sewer system [L/d], $F$ as the fraction of the Mexican population living in the MCMA (0.19), and $E$ as the excretion rate of the respective pharmaceutical (Table 2).

Correlations between irrigation time of sites and their concentrations of resistance genes, Enterococcus 23S rDNA genes, and total concentrations of $16 \mathrm{~S}$ rDNA genes were analyzed for statistical significance with the Spearman rank correlation coefficient and Kendalls tau using the Statistica 8.0 software (Statsoft, Tulsa, USA).

\section{Results and Discussion}

\section{Pharmaceuticals}

Soils under rain-fed agriculture contained on average $0.2 \mu \mathrm{g} / \mathrm{kg}$ of the analyzed pharmaceuticals. Potential reasons for the detection of these chemicals in non-irrigated soils are for example the deposition of wastewater aerosol close to irrigation channels, deposition of soil material derived from neighboring irrigated sites by wind erosion, or the transport of soil material between fields with farm machinery. Differences between the concentration levels of pharmaceuticals, their disposition to accumulation, and their bioaccessibility were observed between non-irrigated soils and irrigated soils as well as among irrigated soils. Total extractable concentrations of pharmaceuticals in irrigated soils averaged over the four parcels of each plot reached a maximum of $8.38 \mu \mathrm{g} / \mathrm{kg}$ soil (Table $\mathrm{S} 6$ in the SI). Concentrations of the acidic pharmaceuticals naproxen, diclofenac, and bezafibrate ranged between $\quad 0.51-3.06 \mu \mathrm{g} / \mathrm{kg}, \quad 0.10-0.54 \mu \mathrm{g} / \mathrm{kg}, \quad$ and $<\mathrm{LOD}-1.07 \mu \mathrm{g} / \mathrm{kg}$, respectively. Similar results were obtained by Gibson et al. [13] for naproxen $(0.27-0.61 \mu \mathrm{g} / \mathrm{kg})$ and diclofenac $(<\mathrm{LOD})$ for soils of the Mezquital Valley. The concentrations of these acidic pharmaceuticals in soils did not increase with increasing time of wastewater irrigation (Table S6). This lack of accumulation confirms the results of Siemens et al. [14,60] and Durán-Álvarez et al. [61] regarding the poor retardation of these compounds in soil. Due to the alkaline $\mathrm{pH}$ values of the wastewater and the receiving soils that exceed the acid dissociation constants of naproxen, diclofenac, and bezafibrate, these compounds occur as negatively charged species. This negative charge counteracts sorption to negatively charged clays and moieties of soil organic matter [14], also expressed by small $\mathrm{K}_{\mathrm{OC}}$ values at near neutral $\mathrm{pH}$ (Table 2). In the column experiments of Siemens et al. [60] with soil from the Mezquital Valley degradation of naproxen could not be detected while bezafibrate transport could be described with a first order degradation rate constant of $0.033 \pm 0.03 / \mathrm{h}$.

The antibiotic sulfamethoxazole and the anticonvulsant carbamazepine were detected with the largest range of concentrations in irrigated soils, spanning from $0.98-5.96 \mu \mathrm{g} / \mathrm{kg}$ for sulfamethoxazole and from $1.49-8.38 \mu \mathrm{g} / \mathrm{kg}$ for carbamazepine. Carbamazepine concentrations are in accordance with the findings of Gibson et al. [13], who detected concentrations in the A horizon of soils in the Mezquital Valley ranging from 2.6 to $7.5 \mu \mathrm{g} / \mathrm{kg}$. Total soil concentrations of the antibiotics trimethoprim (0.13-2.44 $\mu \mathrm{g}$ / $\mathrm{kg}$ ) and ciprofloxacin $(0.35-2.62 \mu \mathrm{g} / \mathrm{kg})$ were smaller, despite the fact that their predicted concentrations in wastewater (PEC: 1.05 and $0.30 \mu \mathrm{g} / \mathrm{L}$, respectively) were larger than for carbamazepine (PEC: $0.03 \mu \mathrm{g} / \mathrm{L}$ ). For clarithromycin, the largest concentration found in our study was $5.43 \mu \mathrm{g} / \mathrm{kg}$, but this concentration was only present in one plot. For the other plots, the concentrations of clarithromycin were generally smaller $(<3 \mu \mathrm{g} / \mathrm{kg})$, in line with comparably smaller predicted concentrations of this compound in wastewater (PEC: $0.09 \mu \mathrm{g} / \mathrm{L}$ ). The veterinary antibiotic enrofloxacin was detected in small concentrations between $<$ LOD and $1.21 \mu \mathrm{g} / \mathrm{kg}$ soil, suggesting that not only pharmaceuticals intended for human consumption reach the soils of the Mezquital Valley, but also veterinary pharmaceuticals.

Total concentrations of sulfamethoxazole, ciprofloxacin, and carbamazepine in soils rapidly increased with increasing duration of wastewater irrigation until no further increase of concentration could be observed in soils irrigated for more than approximately 25 years (Figure 1A, 1B, 1C). The 22.6 years of time span for approaching nearly constant concentrations of total extractable ciprofloxacin in soil matches almost exactly the time since when this compound was on the market. It was introduced 1983 and approved by the U.S. Federal Drug Administration in 1987. The plateau of total extractable ciprofloxacin concentrations therefore might be influenced by the point of time when this drug was first released into the environment and not unequivocally indicate a steady state between input and dissipation. Given the long persistence of ciprofloxacin [62], the concentration of only $1.5 \mu \mathrm{g}$ / $\mathrm{kg}$ that is approached after 25 years appears rather small. We suspect that this small concentration is explained by the strong sorption [63] and poor extractability of ciprofloxacin. Sorption of ciprofloxacin takes place predominantly via cation exchange or cation bridges (especially with $\mathrm{Ca}^{2+}$, [64]) or both. The large cation exchange capacity and $\mathrm{Ca}^{2+}$ saturation of the soils of the Mezquital Valley [65] therefore favor the sorption of ciprofloxacin. Moreover, ciprofloxacin occurs in its zwitterionic form at the 

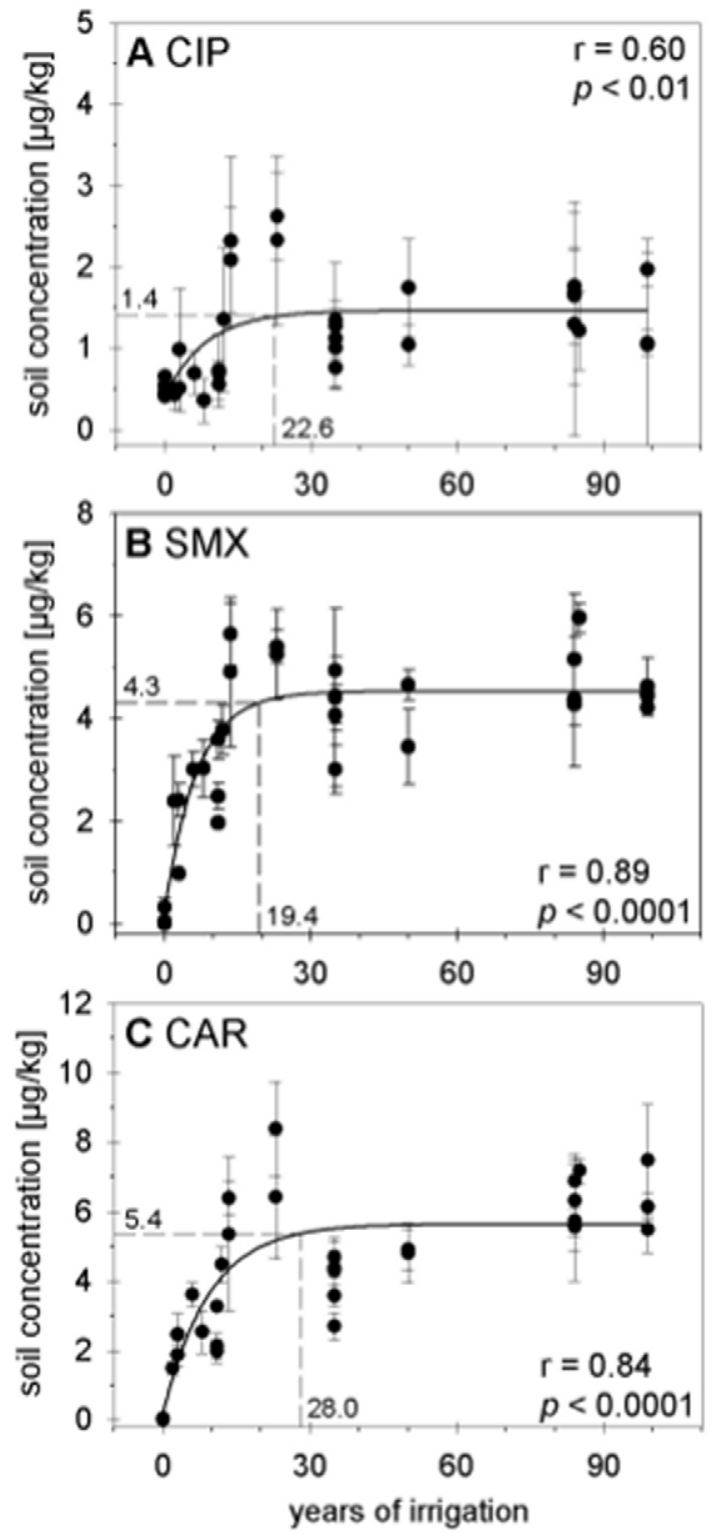

Figure 1. Concentrations of ciprofloxacin (CIP), sulfamethoxazole (SMX), and carbamazepine (CAR) in soils irrigated repeatedly with untreated wastewater. Irrigation took place for different numbers of years. The displayed total concentrations were calculated as the sum of $\mathrm{CaCl}_{2}$-extractable and ASE-extractable concentrations (Figure S1 in the supporting online information). Error bars indicate the standard deviation of concentrations in four quadrant parcels of individual fields. Dashed lines mark the irrigation time until $95 \%$ of the upper limit concentration is reached.

doi:10.1371/journal.pone.0045397.g001

neutral to slightly alkaline $\mathrm{pH}$ of the Mezquital Valley soils and this species is sorbed most effectively [63]. Among different soil types, Vertisols similar to those occurring in the Mezquital Valley sorbed ciprofloxacin most strongly in experiments of Vasudevan et al. [66].

In contrast to ciprofloxacin, sulfamethoxazole and carbamazepine were introduced into clinical practice much earlier (i.e., in the 1960's). Nevertheless, we did not observe a prolonged accumulation of these two compounds for more than 19 and 28 years, respectively (Figure 1B, 1C). Moreover, the final concentrations of sulfamethoxazole $(4.3 \mu \mathrm{g} / \mathrm{kg})$ appear small given the large PEC of this compound in relation to PECs of other compounds (PEC: $1.96 \mu \mathrm{g} / \mathrm{L})$. These rather small concentrations are probably not related to a strong binding or poor extractability, because also the $\log \mathrm{P}_{\text {ow }}$ of sulfamethoxazole is low (0.66; Table 2). Instead, the short half live of only two days that Liu et al. [67] observed for sulfamethoxazole in non-sterile soil, but not in sterile soil suggests that small concentrations of this compound after long-term irrigation are a consequence of effective biodegradation. Overall, large input concentrations of sulfamethoxazole in combination with only moderate sorption and fast dissipation suggest that the plateau concentration of $4.3 \mu \mathrm{g} / \mathrm{kg}$ in the soils of the Mezquital Valley is likely reflecting a steady state equilibrium between input and dissipation.

Despite a more than 180 times smaller predicted concentration in wastewater of only $0.03 \mu \mathrm{g} / \mathrm{L}$, carbamazepine reached a higher plateau concentration of $5.4 \mu \mathrm{g} / \mathrm{kg}$ in the Mezquital Valley soils over time (Figure 1C). This stronger accumulation in comparison to sulfamethoxazole was on the one hand favored by a smaller water solubility, which correlated with retention of pharmaceuticals in the Mezquital Valley soil in the transport study of Siemens et al. [60]. Large contents of soil organic matter in the topsoils of the Mezquital Valley favor the sorption of this neutral compound [68], which is also indicated by a correlation between organic carbon content and carbamazepine concentration reported by Gibson et al. [13] and a comparably high $\mathrm{K}_{\mathrm{OC}}$ value (Table 2). On the other hand, and possibly most important for the observed accumulation of carbamazepine, is its pronounced recalcitrance against biodegradation [69,70,71].

Differences in the accumulation of compounds were not only observed between the pharmaceuticals but also between the different soil types. Total extracted concentrations of pharmaceuticals in Vertisols did not increase with irrigation time (Figure 2A2C). This is at least partly due to the fact that Vertisols under rainfed agriculture or with very short irrigation history were not analyzed because they are rare and we thus did not find such in the Mezquital Valley. In contrast, accumulation of sulfamethoxazole and carbamazepine in Leptosols followed a saturation function until a "steady-state" was approached (defined here as 95\% of final concentration). Different from Leptosols, Phaeozems were characterized by a slower and more linear accumulation of ciprofloxacin, sulfamethoxazole, and carbamazepine (Figure 2D-2F). In comparison to Leptosols, Phaeozems are characterized by a thicker solum, resulting in higher fertility and productivity and therefore higher biological activity. These soil specific differences deserve closer inspection in future studies.

From an ecotoxicological point of view, it is crucial whether the observed increase in total contents of certain pharmaceuticals is related to the build-up of a bioaccessible and therefore potentially bioeffective pool of the respective agents. Calcium chlorideextractable concentrations of most agents that are deemed bioaccessible were usually smaller than $1.2 \mu \mathrm{g} / \mathrm{kg}$ (Figure S1A, S1C, S1E; Table S7). Maximum bioaccessible sulfamethoxazole concentrations equaled only one tenth of the respective total concentrations, and there was no increase of these concentrations over time, likely because efficient degradation [67] prevented the accumulation of easily accessible sulfamethoxazole. Only for the more recalcitrant compound carbamazepine a significant accumulation of $\mathrm{CaCl}_{2}$-extractable concentrations could be identified (Figure S1E).

An important question is whether the accumulation of pharmaceuticals, particularly of the antibiotic agents sulfamethoxazole and ciprofloxacin, affects the abundance of related sul and $q n r$ resistance genes in the soils. 


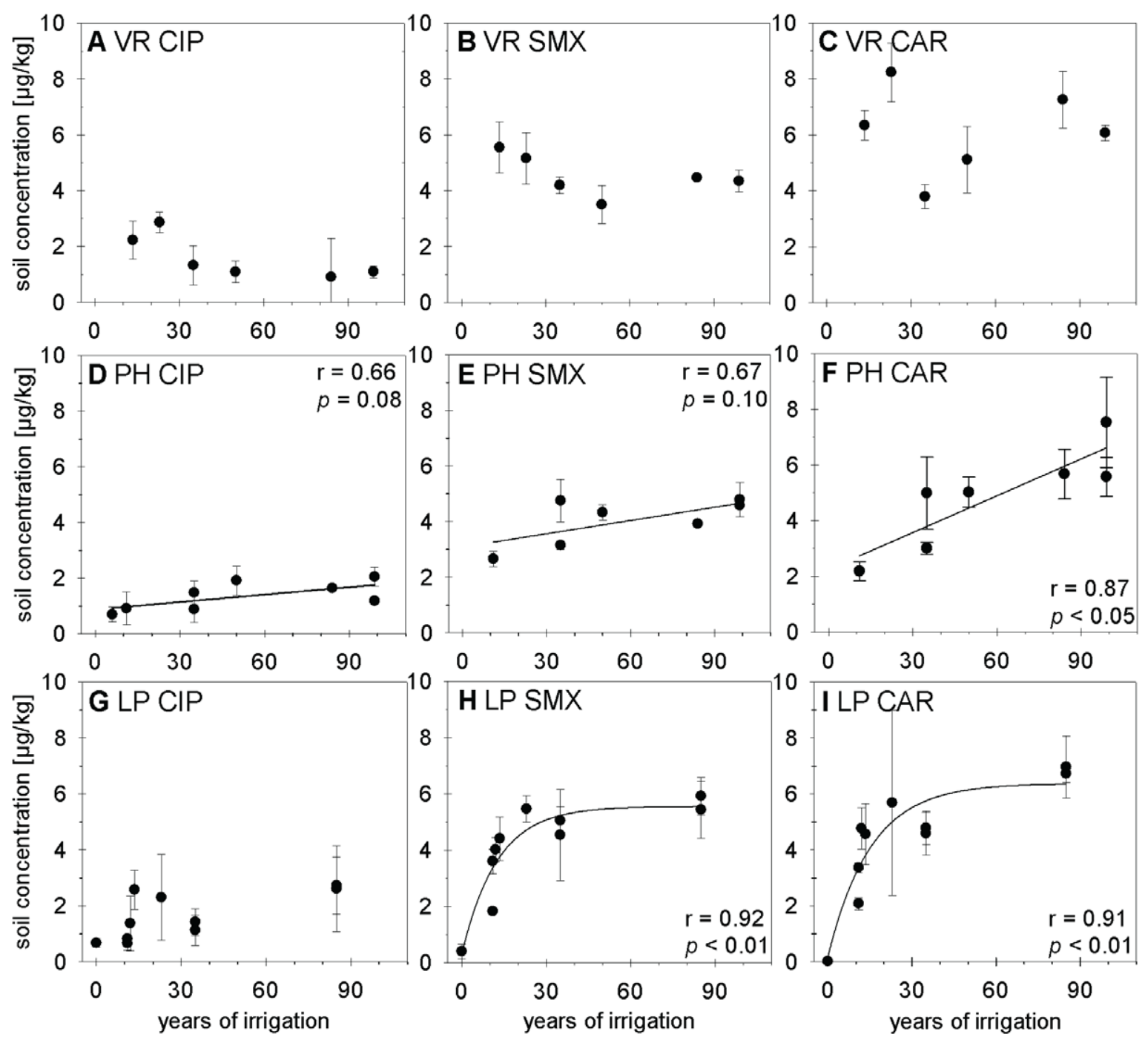

Figure 2. Concentrations of ciprofloxacin (CIP), sulfamethoxazole (SMX), and carbamazepine (CAR) in different soil types. Soils are classified as Vertisols (VR; panel A-C), Phaeozems (PH; panel D-F), and Leptosols (LP; panel G-I). Soils were irrigated repeatedly with untreated wastewater for different numbers of years; error bars indicate the standard deviation of concentrations in four quadrant parcels of individual fields. doi:10.1371/journal.pone.0045397.g002

\section{Antibiotic Resistance Genes and Enterococci}

The sul1 and sul2 genes were present in all soils, even in those under rain-fed agriculture. Possible explanations are the presence of these genes in the "native" resistome of these soils, deposition of aerosols from wastewater-channels, or transport of resistant bacteria via dust or direct fertilization with human or animal excrements [41] or both. Absolute copy numbers of sul1 resistance genes per $\mathrm{g}$ soil $(\mathrm{DM})$ in irrigated soils exceeded those in soils under rain-fed agriculture by a factor of approximately 150-1500 (Figure 3A; exact numbers of resistance genes are provided in Tables S8 in the SI). There was a significant correlation between the absolute concentration of sul1 genes and irrigation time (rank correlation coefficients: Kendalls tau $=0.69, \mathrm{p}<0.05$; Spearmans $\mathrm{R}=0.80, \mathrm{p}<0.05)$. The abundance of sul2 in irrigated soils was 50-520 times larger than in soils without wastewater irrigation and also correlated with the duration of irrigation (Kendalls tau $=0.60$ $\mathrm{p}<0.05$; Spearmans $\mathrm{R}=0.75, \mathrm{p}<0.05)$. Hence, and unlike the accumulation of the detected sulfonamide, the abundance of the sul resistance genes continued to increase with increasing time of irrigation.
The absolute concentration of sul1 genes we found in soils under rain-fed agriculture was still considerably smaller than $2.25 \times 10^{4}$ to $7.57 \times 10^{4}$ genes $/ g(D M)$ that Munir and Xagoraraki [40] reported for "background soil" before the application of manure or biosolids. Following the application of manure or biosolids, the copy numbers of sul1 genes in their Michigan soils increased by $36 \%$ (manure) or $14 \%$ (biosolids) compared to background soils, which constitutes a much smaller increase than we observed following wastewater irrigation.

Large absolute numbers of sul resistance genes in soils irrigated with wastewater for prolonged periods of time might be related to large contents of microbial biomass [72] and better survival of wastewater-derived bacteria in soil between irrigation events. To investigate the effect of wastewater-irrigation on the soil bacterial population we determined the total concentration of bacterial DNA by quantitative $16 \mathrm{~S}$ rDNA PCR. The irrigated soils contained on average seven times more 16S rDNA than soils under rain-fed agriculture, and there was a significant correlation between irrigation time and $16 \mathrm{~S}$ rDNA concentration in soil (Figure 4A; Kendalls tau $=0.74, \mathrm{p}<0.05$; Spearmans $\mathrm{R}=0.86$, 

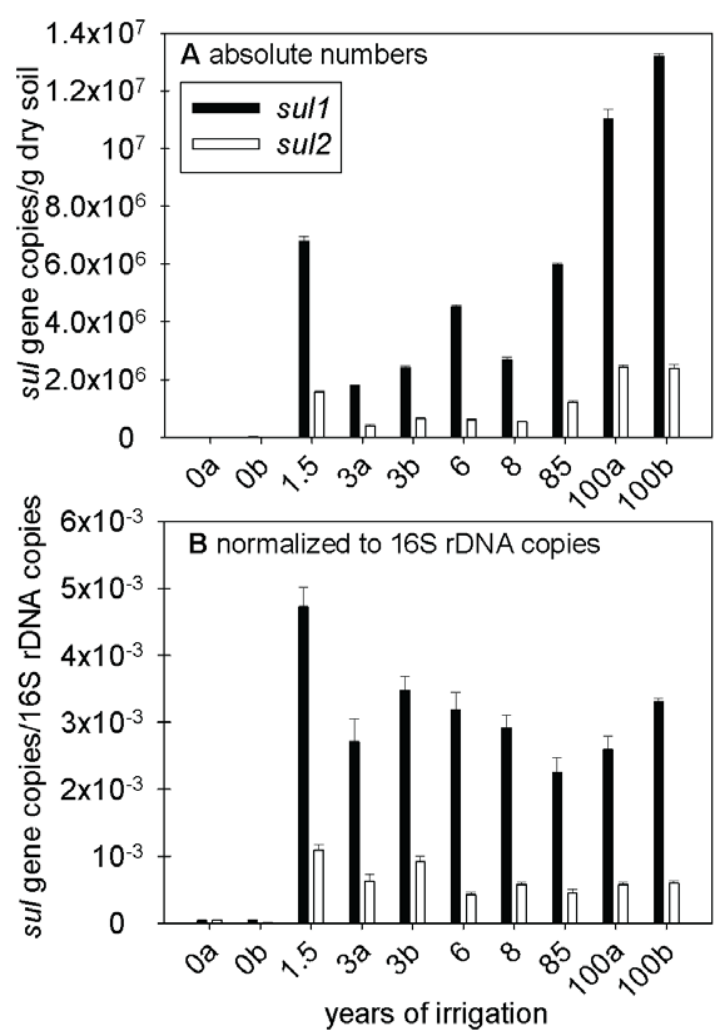

Figure 3. Absolute (panel A) and relative abundance (panel B) of sul1, sul2 resistance genes in soils. Soils were irrigated repeatedly with untreated wastewater for different numbers of years. Error bars indicate the standard deviation between laboratory replications (three replicates) of the same composite soil sample for one field. The small letters " $a$ " and " $b$ " differentiate between fields that have been irrigated for the same period of time. doi:10.1371/journal.pone.0045397.g003

$\mathrm{p}<0.05$; exact numbers of $16 \mathrm{~S}$ rDNA concentrations are provided in Table $\mathrm{S} 9$ in the $\mathrm{SI}$ ). This increase of the total bacterial concentration due to wastewater-irrigation might at least partly be caused by the regular input of bacteria into the soil with wastewater. On the basis of $23 \mathrm{~S}$ rDNA qPCR, we detected Enterococcus spp. in all soils, including soils with rain-fed agriculture. On average, the irrigated soils contained five times more Enterococcus genes than non-irrigated soils, and also the concentration of these genes was significantly correlated with the duration of irrigation (Figure 4B; Kendalls tau $=0.69, \mathrm{p}<0.05$; Spearmans $\mathrm{R}=0.81, \mathrm{p}<0.05$; exact numbers of Enterococcus spp. are provided in Table S9 in the SI).

If the presence of pharmaceuticals, especially the accumulation of sulfamethoxazole and ciprofloxacin, in irrigated soils exerted a selective pressure on soil-dwelling microorganisms, then this should have increased the fraction of these organisms carrying the related sul and $q n r$ resistance genes. This fraction of organisms carrying the respective gene can be expressed by normalizing the number of resistance genes to the concentration of total 16S rDNA. The irrigated soils were characterized by almost two orders of magnitude larger relative concentrations of sul1 genes than the non-irrigated ones, and the relative concentrations of sul2 genes in irrigated soils still exceeded the concentrations in non-irrigated soils on average by a factor of 22 (Figure 3B). However, different from the absolute concentrations discussed above, relative concentrations of sul genes were not correlated with the duration of irrigation: Soils irrigated with wastewater for 100 years did not

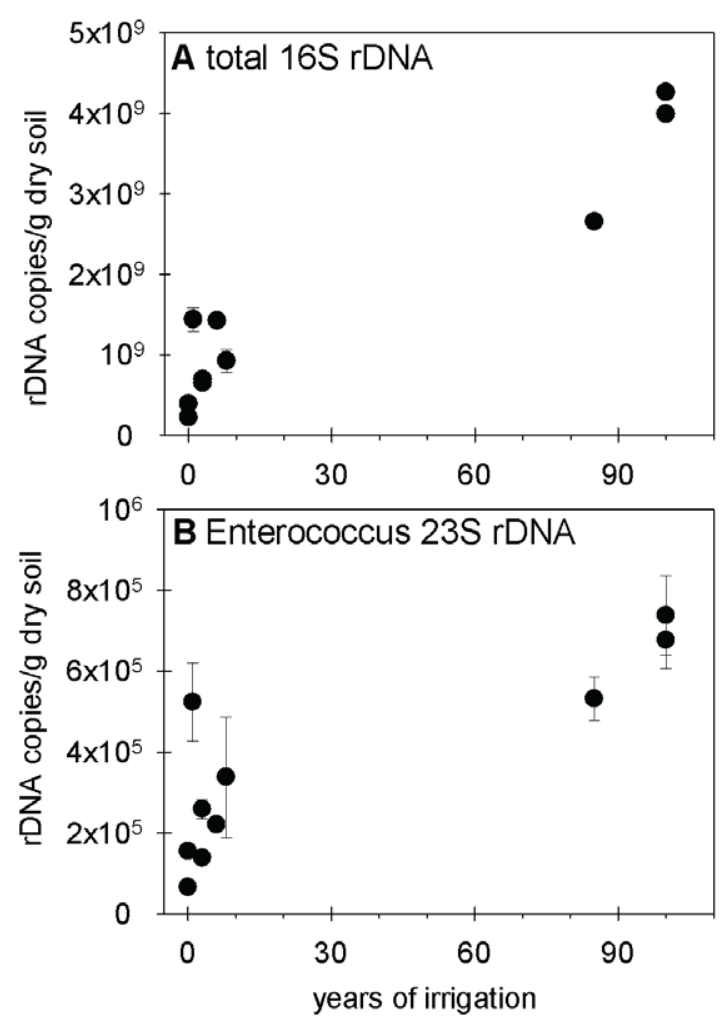

Figure 4. Gene copy numbers of total 16S rDNA (panel A) and Enterococcus spp. (panel B) in soils. Soils were irrigated repeatedly with untreated wastewater for different numbers of years. Error bars indicate the standard deviation between laboratory replications (three replicates) of the same soil sample.

doi:10.1371/journal.pone.0045397.g004

contain more sul resistance genes in relation to their content of $16 \mathrm{~S}$ rDNA than did a soil irrigated with wastewater for 1.5 years (Figure 3B; exact numbers of resistance genes are provided in Table $\mathrm{S} 10$ in the SI).

The relative abundance of sul1 genes in wastewater-irrigated soils was comparable to the relative gene abundance reported by Heuer et al. [38] for a sandy soil treated with manure that contained the sulfonamide antibiotic sulfadiazine, but it was more than two orders of magnitude larger than the relative abundance reported for manure- or biosolid-amended soils by Munir and Xagoraki [40]. The relative abundance of sul2 in the Mexican wastewater-irrigated soils is, however, much smaller than relative abundances of Heuer et al. [38]. Another important difference between the results of Heuer et al. [38] and our results is that repeated applications of sulfadiazine-containing manure caused a successive increase of the relative abundance of sul genes while no such increase was observed after prolonged irrigation with wastewater. Although the direct comparison of results is hampered by the different time-scales that were investigated (193 days in the study of Heuer et al. [38] versus multiple years of irrigation in our study), this difference can probably be related to different concentrations of bioaccessible sulfonamide antibiotics in these studies. The bioaccessible sulfadiazine concentrations in the experiment of Heuer et al [38] exceeded sulfamethoxazole concentrations in the Mezquital Valley soils by more than three orders of magnitude and also increased after repeated manure application, while no such increase of bioaccessible sulfamethoxazole concentrations with increasing irrigation time was observed for the Mexican soils. In another study of Heuer et al. [36], effects 
of sulfadiazine on the relative abundance of sul2 decreased markedly when concentrations dropped below $150 \mu \mathrm{g} / \mathrm{kg}$ soil which is still approximately a factor of 15-30 larger than the concentrations of $\mathrm{CaCl}_{2}$-extractable sulfamethoxazole encountered in the Mezquital Valley soils. The bioaccessible sulfamethoxazole concentration in the soils of the Mezquital Valley thus is probably too small to induce a long-term accumulation of sul genes with increasing time of irrigation. Additionally, the accumulative, sequestered fraction of sulfamethoxazole most likely has no immediate impact on the abundance of sul genes, at least not in the concentration range present in this study.

No qnrA genes encoding fluoroquinolone resistance could be detected in any of the soils. Only $q n r B$ and $q n r S$ were found in two of the chronosequence soils (irrigated for six and 100 years) (Table S8 and Table S10 in the SI). Cummings et al. [37] detected five different quinolone resistance genes, $q n r A$, qnrB, and $q n r S$ amongst others, in surface sediments from a sewage-impacted coastal wetland along the U.S.-Mexico border. Sediments of a nearby urban wetland that was largely unaffected by sewage contained (like the wastewater-irrigated soils) only three different $q n r$ genes, amongst them $q n r B$ and $q n r S$. Nucleotide sequences of cloned $q n r A$ amplicons from the sediment were all similar to qnrA genes encoded on plasmids of clinical isolates, with only one exception. This differs from the present study in which no clinical qnrA genes were detected in the wastewater-irrigated soils of the Mezquital Valley. Although Gullberg et al. [42] showed that ciprofloxacin concentrations of less than $2.5 \mu \mathrm{g} / \mathrm{L}$ can cause selection of resistance in in vitro experiments, increasing total extractable concentrations of ciprofloxacin in soil were not correlated with increasing concentrations of $q n r$ resistance genes. One reason for this might be the strong binding and hence small $\mathrm{CaCl}_{2}$ extractable concentrations of ciprofloxacin that also did not increase with time of irrigation. These results correspond to recent findings of Rosendahl et al. [57], suggesting that although the fluoroquinolone difloxacin is persistent in soil, its bioaccessible concentrations might be too small to affect microbial nitrogen transformation.

\section{Conclusions}

Long-term irrigation of soils with untreated wastewater in the Mezquital Valley led to an accumulation of sulfamethoxazole, ciprofloxacin, and carbamazepine. This accumulation proceeded for a few decades, until after 19 to 28 years an upper limit was approached. This upper limit reflected steady-state conditions between pharmaceutical input and dissipation, but might also have been affected by the history of emissions with wastewater in the case of ciprofloxacin. The (bioaccessible) $\mathrm{CaCl}_{2}$-extractable concentrations of all compounds remained smaller than $1.2 \mu \mathrm{g} /$ $\mathrm{kg}$ soil. Accordingly, the accumulation of sulfamethoxazole and ciprofloxacin in soil with increasing duration of irrigation was not accompanied by an increase of relative abundances of sul and qnr resistance genes. Nevertheless, the regular input of wastewater increased the relative concentrations of resistance genes in irrigated soils relative to soils under rain-fed agriculture. Furthermore, absolute concentrations of sul1 resistance genes increased with increasing duration of irrigation, probably as a consequence of increasing microbial biomass and better survival of wastewaterderived bacteria between irrigation events after long-term irrigation.

\section{Supporting Information}

Figure $\mathrm{S} 1 \mathrm{CaCl}_{2}$-extractable and ASE-extractable concentrations in soils irrigated repeatedly with untreated wastewater for different numbers of years. Error bars indicate the standard deviation of concentrations in four quadrant parcels of individual fields.

(TIF)

Table S1 List of sampled sites.

(DOC)

Table S2 Recoveries of pharmaceuticals during ASEand SPE-extractions.

(DOC)

Table S3 Extraction parameters of the Accelerated Solvent Extraction (ASE).

(DOC)

Table S4 Primers and probes for PGR and qPGR. (DOC)

Table S5 Reagents and programs for qPGR. (DOC)

Table S6 Total extracted pharmaceutical concentrations from soils irrigated repeatedly for different numbers of years with wastewater, standard deviation in brackets.

(DOC)

Table S7 $\mathrm{CaCl}_{2}$ extracted pharmaceutical concentrations from soils irrigated repeatedly for different numbers of years with wastewater, standard deviation in brackets.

(DOG)

Table S8 Concentrations of antibiotic resistance genes (average of gene copies and STD).

(DOC)

Table S9 Concentrations of Enterococcus spp. and $16 \mathrm{~S}$ rDNA (average of gene copies and STD).

(DOC)

Table S10 Relative abundance of antibiotic resistance genes (average values and STD).

(DOC)

Text S1 Extraction of pharmaceuticals from soils. (DOC)

Text S2 LG-MS/MS analysis.

(DOC)

Text S3 Quantification of antibiotic resistance genes and enterococci in soil samples.

(DOC)

\section{Acknowledgments}

We are grateful to Ferran Navarro (Hospital de Sant Pau, Barcelona, Spain) for providing E. coli Hm06-20 and E. coli PS84 and Ørjan Samuelsen (University Hospital of North Norway) for Klebsiella pneumoniae K8-5. We thank Marisa Güttler and Sumati Hohenberger for supporting the extraction of soil samples.

\section{Author Contributions}

Conceived and designed the experiments: CS JH WA EG JS. Performed the experiments: PD MB EW TS. Analyzed the data: PD MB CS EW TS JH WA EG JS. Wrote the paper: PD MB CS EW TS JH WA EG JS. 


\section{References}

1. Baquero F, Alvarez-Ortega C, Martinez JL (2009) Ecology and evolution of antibiotic resistance. Environmental Microbiology Reports 1: 469-476.

2. Canton R (2009) Antibiotic resistance genes from the environment: a perspective through newly identified antibiotic resistance mechanisms in the clinical setting. Clinical Microbiology and Infection 15: 20-25.

3. Wright GD (2010) Antibiotic resistance in the environment: a link to the clinic? Current Opinion in Microbiology 13: 589-594.

4. Heuer H, Schmitt H, Smalla K (2011) Antibiotic resistance gene spread due to manure application on agricultural fields. Current Opinion in Microbiology 14: 236-243.

5. UN/WWAP (2006) 2nd UN World Water Development Report: Water for People, Water for Life. Paris, New York and Oxford: UNESCO (United Nations Educational, Scientific and Cultural Organization) and Berghahn Books.

6. FAO (2007) The state of food and agriculture 2007, Part II. Rome: FAO. 119 $134 \mathrm{p}$.

7. Jiménez Cisneros B (1995) Wastewater reuse to increase soil productivity. Water Science and Technology 32: 173-180.

8. Siebe G (1998) Nutrient inputs to soils and their uptake by alfalfa through longterm irrigation with untreated sewage effluent in Mexico. Soil Use and Management 14: 119-122.

9. Jiménez B, Chávez A (2004) Quality assessment of an aquifer recharged with wastewater for its potential use as drinking source: "El Mezquital Valley" case. Water Science and Technology 50: 269-276.

10. Chávez A, Maya C, Gibson R, Jiménez B (2011) The removal of microorganisms and organic micropollutants from wastewater during infiltration to aquifers after irrigation of farmland in the Tula Valley, Mexico. Environmental Pollution 159: 1354-1362.

11. Raschid-Sally L, Jayakody P (2008) Drivers and characteristics of wastewater agriculture in developing countries-results from a global assessment. Colombo Sri Lanka: IWMI. 38 p.

12. Gibson R, Becerril-Bravo E, Silva-Castro V, Jiménez B (2007) Determination of acidic pharmaceuticals and potential endocrine, disrupting compounds in wastewaters and spring waters by selective elution and analysis by gas chromatography-mass spectrometry. Journal of Chromatography A 1169: 3139.

13. Gibson R, Durán-Álvarez JC, Estrada KL, Chávez A, Jiménez Cisneros B (2010) Accumulation and leaching potential of some pharmaceuticals and potential endocrine disruptors in soils irrigated with wastewater in the Tula Valley, Mexico. Chemosphere 81: 1437-1445.

14. Siemens J, Huschek G, Siebe C, Kaupenjohann M (2008) Concentrations and mobility of human pharmaceuticals in the world's largest wastewater irrigation system, Mexico City-Mezquital Valley. Water Research 42: 2124-2134.

15. Durán-Álvarez JC, Becerril-Bravo E, Castro VS, Jiménez B, Gibson R (2009) The analysis of a group of acidic pharmaceuticals, carbamazepine, and potential endocrine disrupting compounds in wastewater irrigated soils by gas chromatography-mass spectrometry. Talanta 78: 1159-1166.

16. Kinney CA, Furlong ET, Werner SL, Cahill JD (2006) Presence and distribution of wastewater-derived pharmaceuticals in soil irrigated with reclaimed water. Environmental Toxicology and Chemistry 25: 317-326.

17. Ternes TA, Bonerz M, Herrmann N, Teiser B, Andersen HR (2007) Irrigation of treated wastewater in Braunschweig, Germany: An option to remove pharmaceuticals and musk fragrances. Chemosphere 66: 894-904.

18. Chen F, Ying GG, Kong LX, Wang L, Zhao JL, et al. (2011) Distribution and accumulation of endocrine-disrupting chemicals and pharmaceuticals in wastewater irrigated soils in Hebei, China. Environmental Pollution 159: 1490-1498.

19. Tamtam F, van Oort F, Le Bot B, Dinh T, Mompelat S, et al. (2011) Assessing the fate of antibiotic contaminants in metal contaminated soils four years after cessation of long-term waste water irrigation. Science of the Total Environment 409: 540-547.

20. Juárez-Figueroa LA, Silva-Sánchez J, Uribe-Salas FJ, Cifuentes-García E (2003) Microbiological indicators of water quality in the Xochimilco canals, Mexico City. Salud Publica De Mexico 45: 389-395.

21. Mazari-Hiriart M, Ponce-de-León S, López-Vidal Y, Islas-Macías P, Isabel Amieva-Fernández R, et al. (2008) Microbiological Implications of Periurban Agriculture and Water Reuse in Mexico City. Plos One 3.

22. Igbinosa EO, Obi LC, Tom M, Okoh AI (2011) Detection of potential risk of wastewater effluents for transmission of antibiotic resistance from Vibrio species as a reservoir in a peri-urban community in South Africa. International Journal of Environmental Health Research 21: 402-414.

23. Ansari MI, Grohmann E, Malik A (2008) Conjugative plasmids in multi-resistant bacterial isolates from Indian soil. Journal of Applied Microbiology 104: 1774 1781.

24. Frahm E, Obst U (2003) Application of the fluorogenic probe technique (TaqMan PCR) to the detection of Enterococcus spp. and Escherichia coli in water samples. Journal of Microbiological Methods 52: 123-131.

25. da Silva MF, Tiago I, Verissimo A, Boaventura RAR, Nunes OC, et al. (2006) Antibiotic resistance of enterococci and related bacteria in an urban wastewater treatment plant. Fems Microbiology Ecology 55: 322-329.

26. Kuhn I, Iversen A, Burman LG, Olsson-Liljequist B, Franklin A, et al. (2003) Comparison of enterococcal populations in animals, humans, and the environment - a European study. International Journal of Food Microbiology 88: $133-145$.

27. Abriouel H, Ben Omar N, Molinos AC, Lopez RL, Grande MJ, et al. (2008) Comparative analysis of genetic diversity and incidence of virulence factors and antibiotic resistance among enterococcal populations from raw fruit and vegetable foods, water and soil, and clinical samples. International Journal of Food Microbiology 123: 38-49.

28. da Costa PM, Vaz-Pires P, Bernardo F (2006) Antimicrobial resistance in Enterococcus spp. isolated in inflow, effluent and sludge from municipal sewage water treatment plants. Water Research 40: 1735-1740.

29. Werner G, Coque TM, Hammerum AM, Hope R, Hryniewicz W, et al. (2008) Emergence and spread of vancomycin resistance among enterococci in Europe. Euro surveillance : bulletin europeen sur les maladies transmissibles = European communicable disease bulletin 13 .

30. Vincent J-L, Norrenberg M (2009) Intensive care unit-acquired weakness: framing the topic. Critical care medicine 37: S296-298.

31. Sava IG, Heikens E, Kropec A, Theilacker C, Willems R, et al. (2010) Enterococcal surface protein contributes to persistence in the host but is not a target of opsonic and protective antibodies in Enterococcus faecium infection. Journal of Medical Microbiology 59: 1001-1004.

32. Theilacker C, Kaczynski Z, Kropec A, Sava I, Ye L, et al. (2011) Serodiversity of Opsonic Antibodies against Enterococcus faecalis -Glycans of the Cell Wall Revisited. Plos One 6.

33. Rysz M, Alvarez PJJ (2004) Amplification and attenuation of tetracycline resistance in soil bacteria: aquifer column experiments. Water Research 38: 3705-3712.

34. Heuer H, Smalla K (2007) Manure and sulfadiazine synergistically increased bacterial antibiotic resistance in soil over at least two months. Environmental Microbiology 9: 657-666.

35. Binh CTT, Heuer H, Kaupenjohann M, Smalla K (2008) Piggery manure used for soil fertilization is a reservoir for transferable antibiotic resistance plasmids. FEMS Microbiology Ecology 66: 25-37.

36. Heuer H, Focks A, Lamshoeft M, Smalla K, Matthies M, et al. (2008) Fate of sulfadiazine administered to pigs and its quantitative effect on the dynamics of bacterial resistance genes in manure and manured soil. Soil Biology \& Biochemistry 40: 1892-1900.

37. Cummings DE, Archer KF, Arriola DJ, Baker PA, Faucett KG, et al. (2011) Broad Dissemination of Plasmid-Mediated Quinolone Resistance Genes in Sediments of Two Urban Coastal Wetlands. Environmental Science \& Technology 45: 447-454.

38. Heuer H, Solehati O, Zimmerling U, Kleineidam K, Schloter M, et al. (2011) Accumulation of Sulfonamide Resistance Genes in Arable Soils Due to Repeated Application of Manure Containing Sulfadiazine. Applied and Environmental Microbiology 77: 2527-2530.

39. Kristiansson E, Fick J, Janzon A, Grabic R, Rutgersson C, et al. (2011) Pyrosequencing of Antibiotic-Contaminated River Sediments Reveals High Levels of Resistance and Gene Transfer Elements. Plos One 6.

40. Munir M, Xagoraraki I (2011) Levels of Antibiotic Resistance Genes in Manure, Biosolids, and Fertilized Soil. Journal of Environmental Quality 40: 248-255.

41. Allen HK, Donato J, Wang HH, Cloud-Hansen KA, Davies J, et al. (2010) Call of the wild: antibiotic resistance genes in natural environments. Nature Reviews Microbiology 8: 251-259.

42. Gullberg E, Cao S, Berg OG, Ilback C, Sandegren L, et al. (2011) Selection of Resistant Bacteria at Very Low Antibiotic Concentrations. Plos Pathogens 7, e1002158.

43. Byrne-Bailey KG, Gaze WH, Kay P, Boxall ABA, Hawkey PM, et al. (2009) Prevalence of Sulfonamide Resistance Genes in Bacterial Isolates from Manured Agricultural Soils and Pig Slurry in the United Kingdom. Antimicrobial Agents and Chemotherapy 53: 696-702.

44. Schluter A, Heuer H, Szczepanowski R, Forney LJ, Thomas CM, et al. (2003) The 64508 bp IncP-1 beta antibiotic multiresistance plasmid pB10 isolated from a waste-water treatment plant provides evidence for recombination between members of different branches of the IncP-1 beta group. Microbiology 149: 3139-3153.

45. Nordmann P, Poirel L (2005) Emergence of plasmid-mediated resistance to quinolones in Enterobacteriaceae. Journal of Antimicrobial Chemotherapy 56: 463-469.

46. Strahilevitz J, Jacoby GA, Hooper DC, Robicsek A (2009) Plasmid-Mediated Quinolone Resistance: a Multifaceted Threat. Clinical Microbiology Reviews 22: $664+$.

47. Frank T, Gautier V, Talarmin A, Bercion R, Arlet G (2007) Characterization of sulphonamide resistance genes and class 1 integron gene cassettes in Enterobacteriaceae, Central African Republic (CAR). Journal of Antimicrobial Chemotherapy 59: 742-745.

48. Oyamada Y, Ito H, Inoue M, Yamagishi J-i (2006) Topoisomerase mutations and efflux are associated with fluoroquinolone resistance in Enterococcus faecalis. Journal of Medical Microbiology 55: 1395-1401.

49. Dashti AA, Paton R, Amyes SGB (2006) Linkage of ciprofloxacin resistance with a single genotypic cluster of Klebsiella pneumoniae. International Journal of Antimicrobial Agents 27: 73-76. 
50. Arsene S, Leclercq R (2007) Role of a $q n r$-like gene in the intrinsic resistance of Enterococcus faecalis to Fluoroquinolones. Antimicrobial Agents and Chemotherapy 51: 3254-3258.

51. Wang A, Yang Y, Lu Q, Wang Y, Chen Y, et al. (2008) Presence of $q n r$ gene in Escherichia coli and Klebsiella pneumoniae resistant to ciprofloxacin isolated from pediatric patients in China. BMC Infectious Diseases 8.

52. Preger AC, Koesters R, Du Preez CC, Brodowski S, Amelung W (2010) Carbon sequestration in secondary pasture soils: a chronosequence study in the South African Highveld. European Journal of Soil Science 61: 551-562.

53. Gulde S, Chung H, Amelung W, Chang C, Six J (2008) Soil carbon saturation controls labile and stable carbon pool dynamics. Soil Science Society of America Journal 72: 605-612.

54. Lobe I, Bol R, Ludwig B, Du Preez CC, Amelung W (2005) Savanna-derived organic matter remaining in arable soils of the South African Highveld longterm mixed cropping: Evidence from C-13 and N-15 natural abundance. Soil Biology \& Biochemistry 37: 1898-1909.

55. IUSS (2006) Working Group WRB: World Reference Base for Soil Resources 2006. Rome: FAO

56. IMS (2008) IMS chemical country profile Mexico. London: IMS Health Incorporated.

57. Rosendahl I, Siemens J, Kindler R, Groeneweg J, Zimmermann J, et al. (2012) Persistence of the fluoroquinolone antibiotic difloxacin in soil and lacking effects on N-turnover. Environmental Quality 41: 1275-1283.

58. Golet EM, Strehler A, Alder AC, Giger W (2002) Determination of fluoroquinolone antibacterial agents in sewage sludge and sludge-treated soil using accelerated solvent extraction followed by solid-phase extraction. Analytical Chemistry 74: 5455-5462.

59. Gobel A, Thomsen A, McArdell CS, Alder AC, Giger W, et al. (2005) Extraction and determination of sulfonamides, macrolides, and trimethoprim in sewage sludge. Journal of Chromatography A 1085: 179-189.

60. Siemens J, Huschek G, Walshe G, Siebe C, Kasteel R, et al. (2010) Transport of Pharmaceuticals in Columns of a Wastewater-Irrigated Mexican Clay Soil. Journal of Environmental Quality 39: 1201-1210.

61. Durán-Álvarez JC, Prado-Pano B, Jiménez-Cisneros B (2012) Sorption and desorption of carbamazepine, naproxen and triclosan in a soil irrigated with raw wastewater: Estimation of the sorption parameters by considering the initial mass of the compounds in the soil. Chemosphere 88: 84-90.

62. Wu C, Spongberg AL, Witter JD (2008) Determination of the persistence of pharmaceuticals in biosolids using liquid-chromatography tandem mass spectrometry. Chemosphere 73: 511-518.
63. Conkle JL, Lattao C, White JR, Cook RL (2010) Competitive sorption and desorption behavior for three fluoroquinolone antibiotics in a wastewater treatment wetland soil. Chemosphere 80: 1353-1359.

64. Wang C-J, Li Z, Jiang W-T, Jean J-S, Liu C-C (2010) Cation exchange interaction between antibiotic ciprofloxacin and montmorillonite. Journal of Hazardous Materials 183: 309-314.

65. Siebe C, Cifuentes E (1995) Environmental impact of wastewater irrigation in central Mexico: An overview. International Journal of Environmental Health Research 5: 161-173.

66. Vasudevan D, Bruland GL, Torrance BS, Upchurch VG, MacKay AA (2009) $\mathrm{pH}$-dependent ciprofloxacin sorption to soils: Interaction mechanisms and soil factors influencing sorption. Geoderma 151: 68-76.

67. Liu F, Ying GG, Yang JF, Zhou LJ, Tao R, et al. (2010) Dissipation of sulfamethoxazole, trimethoprim and tylosin in a soil under aerobic and anoxic conditions. Environmental Chemistry 7: 370-376.

68. Chefetz B, Mualem T, Ben-AriJ (2008) Sorption and mobility of pharmaceutical compounds in soil irrigated with reclaimed wastewater. Chemosphere 73: 13351343 .

69. Miao XS, Yang JJ, Metcalfe CD (2005) Carbamazepine and its metabolites in wastewater and in biosolids in a municipal wastewater treatment plant. Environmental Science \& Technology 39: 7469-7475.

70. Carballa M, Omil F, Ternes T, Lema JM (2007) Fate of pharmaceutical and personal care products (PPCPs) during anaerobic digestion of sewage sludge. Water Research 41: 2139-2150.

71. Monteiro SC, Boxall ABA (2010) Occurrence and Fate of Human Pharmaceuticals in the Environment. Reviews of Environmental Contamination and Toxicology, Vol 202 202: 53-154.

72. Friedel JK, Langer T, Siebe C, Stahr K (2000) Effects of long-term waste water irrigation on soil organic matter, soil microbial biomass and its activities in central Mexico. Biology and Fertility of Soils 31: 414-421.

73. Siebe C (1994) Akkumulation, Mobilität und Verfügbarkeit von Schwermetallen in längjährig mit städtischen Abwässern bewässerten Böden in Zentralmexiko. Stuttgart: Universität Hohenheim.

74. Verlicchi P, Galletti A, Petrovic M, Barcelo D (2010) Hospital effluents as a source of emerging pollutants: An overview of micropollutants and sustainable treatment options. Journal of Hydrology 389: 416-428.

75. Figueroa-Diva RA, Vasudevan D, MacKay AA (2010) Trends in soil sorption coefficients within common antimicrobial families. Chemosphere 79: 786-793.

76. Barron L, Havel J, Purcell M, Szak M, Kelleher B, et al. (2009) Predicting sorption of pharmaceuticals and personal care products onto soil and digested sludge using artificial neural networks. Analyst 134: 663-670. 